\title{
PENGELOLAAN DANA ZAKAT UNTUK PEMBIAYAAN PENDIDIKAN ANAK DHUAFA (Studi Kasus Pada BAZNAS Kabupaten Kepulauan Meranti)
}

\author{
Nur Sakinah $^{1}$ \& Husni Thamrin ${ }^{2}$ \\ ${ }^{1 \& 2}$ Program Studi Ekonomi Syariah, Fakultas Pasca Sarjana \\ UIN Suska Riau \\ Email:22090321972@students.uin-suska.ac.id,husni2017husni@gmail.com
}

\begin{abstract}
Abstrak
Penelitian ini bertujuan untuk mengetahui bagaimana pengelolaan dana zakat untuk pembiayaan pendidikan anak dhuafa dan untuk mengetahui kriteria siswa penerima pembiayaan pendidikan oleh BAZNAS Kabupaten Kepulauan Meranti. Pendekatan dalam penelitian ini adalah pendekatan kualitatif dengan desain penelitian studi kasus. Metode pengumpulan data dalam penelitian ini dilakukan dengan observasi, wawancara dan dokumentasi. Hasil penelitian menunjukkan bahwa dana zakat yang telah dikumpulkan oleh BAZNAS Kabupaten Kepulauan Meranti akan didistribusikan ke dalam 6 program yakni program Meranti Agamis, Meranti Cerdas, Meranti Produktif, Meranti Sehat, Meranti Peduli dan Meranti Konsumtif. Pengelolaan dana zakat untuk pembiayaan pendidikan disalurkan pada program Meranti Cerdas. Kriteria siswa penerima pembiayaan pendidikan oleh BAZNAS Kabupaten Kepulauan Meranti digolongkan berdasarkan skala prioritas: fakir miskin atau yatim piatu, beragama Islam, masih sekolah, adanya surat keterangan tidak mampu dari RT setempat, anak yang tergolong pintar dan berdomisili di Kabupaten Kepulauan Meranti.
\end{abstract}

Kata Kunci: BAZNAS, Pengelolaan Zakat, Pembiayaan Pendidikan.

\begin{abstract}
This study aims to find out how the management of zakat funds for the financing of children's education dhuafa and to know the criteria of students receiving education financing by BAZNAS Meranti Islands Regency. The approach in this research is qualitative approach with case study research design. Data collection method in this research was conducted by observation, interview and documentation. The results showed that the zakat funds that have been collected by BAZNAS Meranti Islands district will be distributed into 6 programs, namely Meranti Agamis, Meranti Cerdas, Meranti Produktif, Meranti Sehat, Meranti Peduli and Meranti Consumptive programs. The management of zakat funds for education financing is channeled to the Meranti Cerdas program. The criteria of students receiving education financing by BAZNAS Meranti Islands district are classified based on priority scale: poor or orphaned, Muslim, still in school, the existence of a certificate of incapability from the local RT, children who are classified as smart and domiciled in meranti islands.
\end{abstract}

Keywords: BAZNAS, Zakat Management, Education Financing. 


\section{PENDAHULUAN}

Meningkatkan mutu pendidikan merupakan salah satu cara yang terbaik untuk menaikkan kualitas sumber daya manusia. Salah satu akar permasalahan pendidikan pada umumnya terletak pada pembiayaan. Orang tua yang tidak memiliki keuangan cukup untuk membiayai pendidikan anaknya karena pendapatannya tergolong rendah, dan tidak sebanding dengan begitu tingginya biaya pendidikan yang harus ditanggung. Oleh karena itu tanpa adanya peningkatan pembiayaan dari pemerintah, maka jelas pendidikan di Indonesia ini sangat sulit untuk keluar dari krisis. Kondisi yang seperti ini dapat menyebabkan negeri ini akan kehilangan generasi terbaik, dikarenakan generasi yang akan datang adalah generasi yang memiliki kualitas intelektual yang rendah.

Namun demikian ada amanat terobosan tentang Sistem Pendidikan Nasional. Ketentuannya menyebutkan bahwa selain dari sektor APBD dan APBN, pendanaan pendidikan dari masyarakat bisa mencakup sumbangan pendidikan, hibah, wakaf, zakat, pembayaran nadzar, pinjaman, sumbangan perusahaan, keringanan dan penghapusan pajak untuk pendidikan, dan lain-lain penerimaan yang sah (Muhammad, 2004). Hemat penulis bahwa pendidikan ini sangat penting karena merupakan kunci untuk menyiapkan Sumber Daya Manusia (SDM) yang berkompeten dan berkualitas, mampu bersaing serta memiliki nilai keunggulan, sehingga mampu untuk merebut pangsa pasar tenaga kerja dunia dan pada akhirnya tercapailah sebuah kesejahteraan. Oleh karena itu pendidikan yang memiliki kualitas baik hendaknya menjadi sebuah keharusan bagi setiap anak bangsa termasuk mereka yang kurang mampu (anak dhuafa).
Penduduk Indonesia yang terbanyak adalah masyarakat muslim dan bahkan muslim terbanyak di dunia, maka potensi dana zakat juga besar yang bisa dimanfaatkan untuk membantu anak dhuafa memperoleh pendidikan yang berkualitas. Untuk memaksimalkan pengelolaan dan pendistribusian dana tersebut dibutuhkan suatu lembaga sebagai mediator antara mereka yang mampu dan mereka yang berhak menerima. Di Indonesia lembaga pengelola dana zakat yang secara legal diakui oleh pemerintah adalah BAZ (badan amil zakat) dan LAZ (lembaga amil zakat), BAZ adalah lembaga pengelola dana zakat yang dibentuk oleh pemerintah, sedangkan LAZ adalah lembaga pengelola dana zakat yang dijalani oleh swasta yang mendapatkan izin resmi dari pemerintah.

Di Provinsi Riau terdapat lembaga-lembaga atau kelompok masyarakat yang memiliki konsentrasi pada bidang sosial, pendidikan dan sebagainya. Salah satunya yang peduli dengan pendidikan adalah BAZNAS Kabupaten Kepulauan Meranti. Badan Amil Zakat (BAZ) Kabupaten Kepulauan Meranti di dirikan pada tanggal 21 Maret 2011. Badan Amil Zakat (BAZ) Kabupaten Kepulauan Meranti dibentuk dengan tujuan untuk mencapai daya guna dan akuntabilitas dalam proses pengelolaan dana Zakat, Infak dan Sedekah (ZIS) sehingga dengan begitu dapat meningkatkan peran umat Islam yang berada di Kabupaten Kepulauan Meranti dalam rangka pembangunan manusia seutuhnya dengan penggalian dan pengelolaan dana Zakat, Infaq dan Sedekah (ZIS). Penghimpunan dananya diperoleh dari zakat, infaq dan sedekah yang dialokasikan salah satunya pada program pembiayaan pendidikan (Dokumentasi BAZNAS Kabupaten Kepulauan Meranti). 
Zakat, infak dan sedekah memiliki hubungan. Yakni infak mengeluarkan harta karena untuk taat dan patuh kepada Allah, sedekah adalah segala pemberian/kegiatan untuk mengharapkan pahala dari Allah, sedekah ini memiliki dimensi yang lebih luas daripada infak. Walaupun zakat merupakan dimensi yang paling sempit dari infak dan sedekah, namun dia mengikat setiap muslim. Oleh karena itu, para fuqaha biasa menyebutkan zakat sebagai infak wajib dan infak sebagai shadaqah tathawwu' atau sedekah sunah (Nurhayati, 2011). Zakat sangat diharapkan dapat mendatangkan kesuburan dan tumbuhnya pahala-pahala dari amal ini. Selain itu juga diharapkan dapat mensucikan jiwa-jiwa orang yang telah melaksanakan zakat dan harta yang telah dizakati menjadi suci dari hal-hal yang mengotori dari segala sesuatu yang syubhat (Zulkifli, 2014). Kesadaran berzakat perlu ditumbuhkan dalam diri setiap pribadi, tidak berzakat karena terpaksa atau dipaksa apalagi karena malu kepada masyarakat sekitar (Hasan, 2000). Zakat merupakan aset utama yang dinilai sangat berharga, maka zakat diharapkan dapat menyelesaikan permasalahan sosial masyarakat termasuk diantaranya permasalahan pendidikan.

\section{TINJAUAN PUSTAKA}

\section{Pengertian Zakat}

Zakat secara harfiah memiliki dua makna, makna yang pertama yaitu "memurnikan" dan "membersihkan" dalam arti bahwa zakat sebagai ibadah yang dapat memurnikan hati bagi yang menunaikannya dengan menghilangkan sifat kikir semata-mata mengharap ridha Allah SWT. Makna kedua, zakat berarti "kesuburan" dan "pertumbuhan" yang bermakna bahwa pembayaran zakat dirancang untuk memfasilitasi pertumbuhan kekayaan dan semangat diantara para pembayar zakat (Anis, 2016). \begin{tabular}{lrrr}
\multicolumn{1}{c}{ Ryandono } & \multicolumn{2}{c}{ berpendapat } & bahwa \\
zakat adalah salah satu & cara \\
mendistribusikan harta dalam & suatu \\
perekonomian dari mereka yang
\end{tabular} mempunyai harta berlebih kepada mereka yang kekurangan harta. Zakat memberikan dampak yang baik pada sistem perekonomian seperti menyempitnya kesenjangan ekonomi, membangun persaudaraan antar pelaku ekonomi untuk mencapai falah. Sedangkan pendapat Az-Zuhaili mengatakan bahwa zakat secara bahasa berasal dari akar kata bahasa arab zakayazku-zakaatan yang bermakna an-nuwuw wa az-ziyadah, bertambah, berkah, tumbuh, bersih dan baik (Ahmad, 2015).

Apabila zakat dapat diartikan dengan suci dan mensucikan, itu karena zakat bisa mensucikan jiwa dan harta seseorang. Yaitu mensucikan jiwanya dari berbagai bentuk penyakit seperti sombong, tidak peduli dengan masyarakat dan lingkungan, dan lain sebagainya. Dan juga mensucikan hartanya dari yang bukan hak dan miliknya. Karena harta yang dimiliki seseorang tidaklah murni menjadi milik dia sendiri, akan tetapi di dalamnya ada hak orang lain. Jika zakat bermakna berkah itu artinya orang yang selalu membayar zakat hartanya akan selalu dilimpahkan keberkahan oleh Allah SWT. Apabila hartanya berkah biasanya akan berdampak pada keberkahan hidup dan keluarga.

Adapun zakat dalam pengertian syar'i adalah satu bentuk ibadah dengan cara mengambil harta-harta tertentu yang diberikan kepada golongan tertentu yang sesuai dengan syarat-syarat tertentu pula. Ungkapan "harta-harta tertentu" memberikan batasan akan harta yang wajib untuk dizakatkan. Karena tidak semua bentuk harta yang dimiliki harus dizakatkan. Sedangkan ungkapan "golongan tertentu" juga memberikan pengertian bahwa zakat harus diberikan kepada orang-orang yang berhak 
(mustahiq) bukan diberikan kepada yang mau. Adapun kata-kata "syarat-syarat tertentu" menggambarkan kepada kita bahwa ibadah zakat merupakan satu ibadah yang ketentuannya diatur dalam syariat, dan ketentuan itu belum berlaku sebelum syarat-syaratnya terpenuhi seperti sampainya nishab dan haul (Basri, 2010).

Zakat diharapkan akan mendatangkan kesuburan dan tumbuhnya pahala-pahala dari amal ini. Juga diharapkan akan mensucikan jiwa-jiwa orang yang telah berzakat dan harta yang telah dizakati menjadi suci dari hal-hal yang mengotori dari segala sesuatu yang syubhat (Zulkifli, 2014). Kesadaran berzakat perlu ditumbuhkan dalam diri setiap pribadi, tidak berzakat karena terpaksa atau dipaksa apalagi karena malu kepada masyarakat sekitar (Hasan, 2000).

Mengenai zakat ini telah dijelaskan dalam Al-Qur'an. Allah SWT berfirman dalam surah At-Taubah ayat 103:

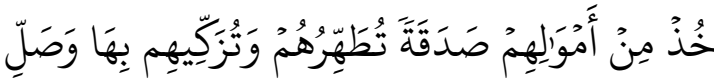

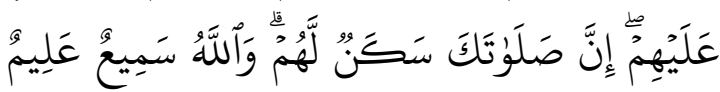

Artinya: "Ambillah zakat dari sebagian harta mereka, dengan zakat itu kamu membersihkan dan mensucikan mereka dan mendoalah untuk mereka. Sesungguhnya doa kamu itu (menjadi) ketenteraman jiwa bagi mereka. Dan Allah SWT Maha Mendengar lagi Maha Mengetahui."

Secara umum, fungsi zakat meliputi bidang moral, sosial, dan ekonomi. Dalam bidang moral, zakat mengikis ketamakan dan keserakahan hati si kaya, sedangkan dalam bidang sosial, zakat berfungsi untuk menghapuskan kemiskinan dari masyarakat (Nurhayati, 2011). Dibidang ekonomi, zakat berfungsi sebagai salah satu instrumen untuk mengentaskan kemiskinan, pemerataan pendapatan, dan mempersempit kesenjangan yang terjadi antara kelompok kaya dan miskin. Zakat juga dapat mempengaruhi kemampuan sebuah komunitas politik (negara) dalam menjalankan kelangsungan hidupnya. Dengan adanya berbagai implikasi moral, sosial dan ekonomi maka zakat dapat membentuk integritas sosial yang kukuh serta memperkuat ketahanan ekonomi masyarakat (Huda, 2010).

Pendapat para ahli ekonomi Islam kontemporer mendefinisikan zakat adalah sebagai harta yang telah ditetapkan oleh pemerintah/pejabat berwenang, kepada masyarakat umum atau individu yang bersifat mengikat dan final, tanpa mendapat imbalan tertentu yang dilakukan oleh pemerintah sesuai dengan kemampuan pemilik harta, yang dialokasikan untuk memenuhi kebutuhan delapan golongan yang telah ditentukan oleh Al-Qur'an serta untuk memenuhi tuntutan politik bagi keuangan Islam (Ali, 2006).

Zakat adalah ibadah maaliyah ijtima 'iyyah, artinya ibadah dibidang harta yang memiliki kedudukan yang sangat penting dalam membangun masyarakat. Jika zakat dikelola dengan baik, baik pengambilan maupun pendistribusiannya, pasti akan dapat mengangkat kesejahteraan masyarakat. Karena itu, di dalam Al-Qur'an dan hadits, banyak perintah untuk berzakat sekaligus pujian bagi yang melakukannya, baik di dunia ini maupun di akhirat nanti. Sebaliknya, banyak pula ayat Al-Qur'an dan hadits Nabi yang mencela orang yang enggan melakukannya, sekaligus ancaman duniawi dan ukhrawi bagi mereka.

Banyak hikmah dan manfaat dari ibadah zakat ini, baik yang akan dirasakan oleh pemberi zakat (muzakki), penerima zakat (mustahik), maupun masyarakat secara keseluruhan. Muzakki akan 
meningkat kualitas keimanannya, rasa syukurnya, kejernihan dan kebersihan jiwa dan hartanya, sekaligus akan mengembangkan harta yang dimilikinya. Mustahik akan meningkat kesejahteraan hidupnya, akan terjaga agama dan akhlaknya, sekaligus akan termotivasi untuk meningkatkan etos kerja dan ibadahnya. Bagi masyarakat luas, hikmah zakat akan dirasakan dalam bentuk tumbuh dan berkembang rasa solidaritas sosialnya, keamanan dan ketentramannya, berputarnya roda ekonomi, karena dengan zakat harta akan didistribusikan dengan baik, sekaligus akan menjaga dan menumbuhkembangkan etika dan akhlak dalam bekerja dan berusaha.

Di dalam menentukan sumber atau objek zakat atau harta yang wajib dikeluarkan zakatnya, Al-Qur'an dan hadits mempergunakan dua metode pendekatan, yaitu pendekatan tafsil (terurai) dan pendekatan ijmal (global). Dengan pendekatan tafsil, Al-Qur'an dan hadits Nabi menjelaskan secara rinci beberapa jenis harta wajib zakat. Pendekatan ijmal dengan cara menyebutkan "harta" dan "hasil usaha". Sehingga dengan menggunakan qiyas (analogi) masalihul-mursalah dan prinsipprinsip umum ajaran Islam, dimungkinkan dan memasukkan semua harta yang di zaman Nabi belum ada contohnya tetapi dianggap "harta yang bernilai" dalam perkembangan ekonomi modern menjadi harta wajib zakat.

\section{Hikmah Zakat}

Hikmah dari pelaksanaan ibadah zakat yakni:

1. Dapat mensucikan diri (pribadi) dari kotoran dosa, memurnikan jiwa (menumbuhkan akhlak mulia menjadi murah hati, peka terhadap rasa kemanusiaan) dan mengikis sifat bakhil (kikir) serta serakah.

2. Membantu orang miskin dan menutup kebutuhan orang yang berada dalam kesulitan dan penderitaan serta memenuhi kebutuhannya untuk menghormati dan melindungi dirinya dari kehinaan minta-minta selain kepada Allah SWT.

3. Memberantas penyakit iri hati, rasa benci dan dengki dari diri orang-orang di sekitarnya berkehidupan cukup, apalagi mewah. Sedang ia sendiri tak memiliki apa-apa dan tidak ada uluran tangan dari orang kaya kepadanya.

4. Dapat menunjang terwujudnya sistem kemasyarakatan Islam yang berdiri atas prinsip-prinsip: ummatan wahidan (umat yang satu), musawah (persamaan derajat, dan kewajiban), ukhuwah Islamiyah (persaudaraan Islam) dan takaful ijtima'i (tanggungjawab bersama).

5. Menjadi unsur penting dalam mewujudkan keseimbangan dalam distribusi harta (social distribution) dan tanggungjawab individu dalam masyarakat.

6. Mempermudah penyaluran harta dari seseorang kepada orang lain sehingga harta tersebut mengalir dan lebih bermanfaat, agar harta tidak beredar dikalangan tertentu, atau hanya beredar dikalangan orang-orang kaya saja (Basri, 2010).

Siapa yang menolak untuk membayar zakat dikarenakan oleh pengingkaran dia akan kewajiban zakat maka telah kafir karena ia telah mengingkari satu bentuk kewajiban bahkan salah satu dari rukun Islam. Akan tetapi siapa yang tidak mau membayar disebabkan oleh sifat bakhilnya maka ia telah melakukan satu dosa dan kefasikan yang akan mendapatkan balasannya dari Allah SWT di akhirat kelak.

\section{Orang-Orang yang Berhak Menerima Zakat}

1. Orang fakir: Orang yang amat sengsara hidupnya, tidak mempunyai 
harta dan tenaga untuk memenuhi penghidupannya.

2. Orang miskin: Orang yang tidak cukup penghidupannya dan dalam keadaan kekurangan.

3. Pengurus zakat: Orang yang diberi tugas untuk mengumpulkan dan membagikan zakat.

4. Muallaf: Orang kafir yang ada harapan masuk Islam dan orang yang baru masuk Islam yang imannya masih lemah.

5. Memerdekan budak: Mencakup juga untuk melepaskan muslim yang ditawan oleh orang-orang kafir.

6. Orang berhutang: Orang yang berhutang karena untuk kepentingan yang bukan maksiat dan tidak sanggup membayarnya. Adapun orang yang berhutang untuk memelihara persatuan umat Islam dibayar hutangnya itu dengan zakat, walaupun ia mampu membayarnya.

7. Pada jalan Allah (Sabilillah): Yaitu untuk keperluan pertahanan Islam dan kaum muslimin. Di antara mufasirin ada yang berpendapat bahwa fisabilillah itu mencakup juga kepentingan-kepentingan umum seperti mendirikan sekolah, rumah sakit dan lain-lain.

8. Orang yang sedang dalam perjalanan yang bukan maksiat mengalami kesengsaraan dalam perjalanannya.

Tidak boleh memberikan zakat kepada orang yang wajib ia nafkahi, seperti ayah bunda, anak-anak, isteri. Zakat juga tidak diberikan kepada ahlul bait, keluarga Rasulullah karena kemuliaan mereka, zakat tidak diberikan kepada orang kafir, fasik (seperti meninggalkan shalat dan melecehkan syarat Islam).

\section{Persyaratan Harta Menjadi Sumber atau Objek Zakat}

Adapun persyaratan harta menjadi sumber atau objek zakat adalah sebagai berikut:

1. Harta tersebut harus didapatkan dengan cara yang baik dan yang halal. Artinya harta yang haram, baik substansi bendanya maupun cara mendapatkannya, jelas tidak dapat dikenakan kewajiban zakat, karena Allah SWT tidak akan menerimanya.

2. Harta tersebut berkembang atau berpotensi untuk dikembangkan seperti melalui kegiatan usaha, perdagangan, melalui pembelian saham, atau ditabungkan, baik dilakukan sendiri maupun bersama orang atau pihak lain.

3. Milik penuh yaitu harta tersebut berada di bawah kontrol dan di dalam kekuasaan pemiliknya, atau seperti menurut sebagian ulama bahwa harta itu berada di tangan pemiliknya, di dalamnya tidak tersangkut dengan hak orang lain, dan ia dapat menikmatinya.

4. Harta tersebut menurut pendapat jumlah ulama harus mencapai nisab yaitu jumlah minimal yang menyebabkan harta terkena kewajiban zakat.

5. Sumber-sumber zakat tertentu seperti perdagangan, peternakan, emas dan perak, harus sudah berada atau dimiliki ataupun diusahakan oleh muzakki dalam tenggang waktu satu tahun.

6. Sebagian ulama mazhab Hanafi mensyaratkan kewajiban zakat setelah terpenuhi kebutuhan pokok atau dengan kata lain zakat dikeluarkan setelah terdapat kelebihan dan kebutuhan hidup sehari-hari yang terdiri atas kebutuhan sandang, pangan dan papan. 


\section{Pengelolaan Dana Zakat}

Pengelolaan zakat adalah suatu kegiatan perencanaan, pengorganisasian, pelaksanaan, pengawasan terhadap pengumpulan dan pendistribusian, serta pendayagunaan zakat. Pengelolaan zakat dilakukan oleh badan amil zakat yang dibentuk oleh pemerintah yang diorganisasikan dalam bentuk suatu badan atau lembaga. Ada dua tujuan dilaksanakannya pengelolaan zakat:

Pertama yaitu meningkatkan pelayanan bagi masyarakat dalam menunaikan zakat sesuai dengan tuntutan agama. Lembaga pengelola zakat harus mampu memaksimalkan seluruh potensi zakat yang ada dari masyarakat, dengan melakukan pengelolaan zakat yang sesuai dengan syariat. Lembaga pengelola zakat harus mampu menumbuhkan kesadaran masyarakat melalui pendekatan yang persuasif yaitu melalui sosialisasi ajaran zakat.

Kedua yaitu meningkatkan fungsi dan peranan keagamaan dalam upaya mewujudkan kesejahteraan masyarakat dan keadilan sosial. Lembaga pengelola zakat merupakan suatu institusi yang dapat dipakai sebagai alat untuk meningkatkan kesejahteraan atau penghapusan kemiskinan, serta dapat mendorong terjadinya keadilan distribusi harta, karena zakat diambilkan dari harta orang-orang kaya untuk kemudian dialokasikan kepada fakir miskin didaerah sekitar pemungutan zakat tersebut.

Pengelolaan zakat oleh lembaga pengelola zakat apalagi yang memiliki kekuatan hukum formal, akan memiliki beberapa keuntungan, antara lain:

1. Untuk menjamin kepastian dan disiplin pembayar zakat.

2. Untuk menjaga perasaan rendah diri para mustahik zakat apabila berhadapan langsung untuk menerima zakat dari para muzakki.
3. Untuk mencapai efesien dan efektifitas serta sasaran yang tepat dalam penggunaan harta zakat menurut skala prioritas yang ada pada suatu tempat.

4. Untuk memperlihatkan syiar Islam dalam semangat penyelenggaraan pemerintahan yang Islami.

Sebaliknya jika zakat diserahkan langsung dari muzakki kepada mustahik, meskipun secara hukum syariah adalah sah, akan tetapi di samping akan terabaikannya hal-hal tersebut di atas, juga hikmah dan fungsi zakat, terutama yang berkaitan dengan kesejahteraan umat, akan sulit diwujudkan (Hafidhudin, 2002).

Sebagaimana diketahui, zakat adalah sedekah yang diwajibkan atas harta seorang muslim yang telah memenuhi syarat, bahkan ia merupakan rukun Islam yang ketiga. Zakat pada dasarnya merupakan sistem yang berfungsi untuk menjamin distribusi pendapatan dan kekayaan masyarakat secara lebih baik. Ia merupakan sebuah sistem yang akan menjaga keseimbangan dan harmoni sosial di antara kelompok kaya (muzakki) dan kelompok miskin (mustahik). Dalam praktiknya pada masa awal Islam, zakat dikelola oleh sebuah komite tetap dari pemerintahan dan menjadi bagian integral dari keuangan negara. Karenanya, kebijakan pengumpulan zakat maupun penyalurannya senantiasa terkait dengan kebijakan pembangunan negara secara keseluruhan. Zakat tidak diperlakukan sebagai sebuah pos ritual belaka, tetapi ia memiliki keterkaitan erat dengan kondisi riil masyarakat dalam suatu negara. Dengan pelembagaan seperti ini, maka efektifitas maupun optimalitas pengelolaan zakat akan lebih terjamin.

Implementasi pengelolaan zakat tidak terbatas pada suatu komunitas muslim kecil, namun melingkupi satu negara. Dalam pemikiran yang ideal, pengelolaan zakat pada era sekarang sebaliknya mengacu pada strategi 
pelembagaan seperti di atas. Namun, jika kondisinya tidak memungkinkan, pelembagaan zakat ini harus dipahami sebagai upaya untuk profesionalisasi pengelolaan zakat sebagai sebuah sistem distribusi kekayaan dan pendapatan yang nyata. Dalam pengertian yang lebih luas, pelembagaan zakat juga bermakna perlunya komitmen yang kuat dan langkah yang konkret dari negara dan masyarakat untuk menciptakan suatu sistem distribusi kekayaan dan pendapatan secara sistemik dan permanen. Langkah ini merupakan wujud nyata yang lain dari upaya menciptakan keadilan sosial. Zakat mencerminkan komitmen sosial dari ekonomi Islam.

\section{Persyaratan Lembaga Pengelola Zakat}

Dalam Fiqh Zakat menyatakan bahwa seseorang yang ditunjuk sebagai amil zakat atau pengelola zakat, harus memiliki beberapa persyaratan sebagai berikut:

1. Beragama Islam. Zakat adalah salah satu urusan utama kaum muslimin yang termasuk rukun Islam (Rukun Islam ketiga), karena itu sudah saatnya apabila urusan penting kaum muslimin ini diurus oleh sesama muslim.

2. Mukallaf yaitu orang dewasa yang sehat akal pkirannya yang siap menerima tanggung jawab mengurus urusan umat.

3. Memiliki sifat amanah atau jujur. Sifat ini sangat penting karena berkaitan dengan kepercayaan umat. Artinya para muzakki akan dengan rela menyerahkan zakatnya melalui lembaga pengelola zakat, jika lembaga ini memang patut dan layak dipercaya. Keamanahan ini diwujudkan dalam bentuk transparansi (keterbukaan) dalam menyampaikan laporan pertanggungjawaban secara berkala dan juga ketepatan penyalurannya sehalan dengan ketentuan syariah Islamiyyah.
4. Mengerti dan memahami hukumhukum zakat yang menyebabkan ia mampu melakukan sosialisasi segala sesuatu yang berkaitan dengan zakat kepada masyarakat. Dengan pengetahuan tentang zakat yang relatif memadai, para amil zakat diharapkan terbebas dari kesalahan dan kekeliruan yang diakibatkan dari kebodohannya pada masalah zakat tersebut. Pengetahuan yang memadai tentang zakat inipun akan mengundang kepercayaan dari masyarakat.

5. Memiliki kemampuan untuk melaksanakan tugas dengan sebaikbaiknya. Amanah dan jujur merupakan syarat yang sangat penting, akan tetapi juga harus ditunjang oleh kemampuan dalam melaksanakan tugas. Perpaduan antara amanah dan kemampuan inilah yang akan menghasilkan kinerja yang optimal.

6. Syarat yang tidak kalah pentingnya adalah kesungguhan amil zakat dalam melaksanakan tugasnya. Amil zakat yang baik adalah amil zakat yang fulltime dalam melaksanakan tugasnya, tidak asal-asalan dan tidak pula sambilan. Banyaknya amil zakat yang sambilan dalam masyarakat kita menyebabkan amil zakat tersebut pasif dan hanya menunggu kedatangan muzakki untuk membayarkan zakatnya atau infaknya. Dan sebagian besar adalah bekerja pada bulan Ramadhan saja.

\section{Biaya Pendidikan}

Pembiayaan dalam kamus besar Bahasa Indonesia adalah semua yang berhubungan membiayai (Depdikbud, 2002). Biaya pendidikan diartikan sebagai jumlah uang yang dihasilkan dan dibelanjakan untuk berbagai keperluan penyelenggaraan pendidikan sekolah yang mencakup gaji guru, peningkatan kemampuan profesional guru, pengadaan perabot/mebeler, pengadaan alat-alat 
pelajaran, alat tulis gambar, kegiatan ekstrakurikuler, kegiatan pengelolaan pendidikan dan supervisi/pembinaan pendidikan, serta ketatausahaan sekolah (Nanang, 2002). Biaya pendidikan adalah nilai uang dalam bentuk moneter (rupiah) dari seluruh sumberdaya (input) yang digunakan dalam penyelenggaraan kegiatan pendidikan pada tingkat satuan pendidikan atau sekolah/madrasah (Nanang, 2007).

Sumber pembiayaan pendidikan pada tingkat makro berasal dari pendapatan negara dari sekitar pajak, pendapatan dari sektor non pajak misalnya dari pemanfaatan sumber daya alam dan produksi nasional lainnya yang pemanfaatannya dalam gas dan non migas, keuntungan dari ekspor barang dan jasa, bantuan dalam bentuk hibah dan pinjaman luar negeri (Dedi, 2003). Sumber dana di lingkungan lembaga pendidikan tidak hanya dari pemerintah melalui APBN dan APBD. Sumber lainnya adalah dari murid/orang tua dalam bentuk sumbangan pembinaan pendidikan (SPP) dan dari sumber masyarakat melalui Badan Pembantu Pembinaan Pendidikan (BP3) (Hadari, 1997).

\section{METODOLOGI PENELITIAN}

Penelitian ini menggunakan pendekatan kualitatif dengan berorientasi pada deskriptif kualitatif. Pendekatan ini dipilih karena dalam penelitian ini mengarah pada pendiskripsian secara rinci dan mendalam mengenai gambaran kondisi yang sebenarnya terjadi di lapangan (Lexy J, 2002). Sedangkan jenis atau desain penelitian adalah Studi Kasus, studi kasus bertujuan mempelajari secara intensif latar belakang, status terakhir dan interaksi lingkungan yang terjadi pada satuan sosial seperti individu, kelompok, lembaga atau komunitas. Dalam Studi Kasus ini meliputi keseluruhan siklus kehidupan atau dapat pula hanya meliputi segmen-segmen tertentu saja, dapat terpusat pada beberapa faktor yang spesifik dan dapat pula memperhatikan keseluruhan elemen (Azwar, 2004).

Pendekatan Kualitatif dan jenis Studi Kasus ditujukan untuk mendapatkan gambaran yang komprehensif dan sistematis terkait pengelolaan dana zakat untuk pembiayaan pendidikan anak dhuafa oleh BAZNAS Kabupaten Kepulauan Meranti. Sehingga diharapkan dari hasil penelitian dapat diketahui, bagaimana kinerja BAZNAS Kabupaten Kepulauan Meranti dalam mengelola dana zakat untuk meningkatkan kualitas pendidikan anak dhuafa. Dalam penelitian ini penulis menggunakan metode pengumpulan data sebagai berikut:

1. Metode Observasi, yakni teknik observasi digunakan untuk menggali data yang berupa peristiwa, tempat atau lokasi dan benda, serta rekaman gambar (H.B. Sutopo, 2002).

\section{Metode Wawancara}

\section{Metode Dokumentasi}

\section{HASIL DAN PEMBAHASAN}

\section{Sekilas Tentang BAZNAS Kabupaten Kepulauan Meranti}

$$
\text { Badan Amil Zakat }
$$

Kabupaten Kepulauan Meranti didirikan pada hari Senin tanggal 21 Maret 2011 berdasarkan Surat Keputusan Bupati Kepulauan Meranti Nomor 76.A Tahun 2011 Tentang Pembentukan Pengurus Badan Amil Zakat Kabupaten Kepulauan Meranti. Sebelum BAZ Kabupaten Kepulauan Meranti dibentuk, pengumpulan dan pengelolaan dana Zakat, Infak dan Sedekah ditangani oleh Badan Amil Zakat Kecamatan Tebing Tinggi. Kecamatan Tebing Tinggi merupakan Unit dari BAZ Kabupaten Bengkalis yang dibentuk sebelum pemekaran Kabupaten Kepulauan Meranti. BAZNAS Kabupaten Kepulauan Meranti Merupakan suatu Badan yang bergerak dalam bidang pelayanan, 
pengumpulan, penyaluran/pendistribusian, pendayagunaan dana zakat, infaq, dan sedekah. BAZNAS Kabupaten Kepulauan Meranti Daerah Selatpanjang beralamat di Komplek Masjid Agung Darul Ulum Jln. Siak Sri Indrapura Selatpanjang.

Berdasarkan undang-undang zakat yang diperbaharui bahwa adanya perubahan nama Badan Amil Zakat (BAZ) menjadi Badan Amil Zakat Nasional (BAZNAS) baik tingkat Pusat maupun Daerah Provinsi dan Kabupaten/Kota. Maka BAZ Kabupaten Kepulauan Meranti merubah nama BAZ menjadi BAZNAS Kabupaten Kepulauan Meranti. Seiring berjalannya waktu BAZNAS Kabupaten Kepulauan Meranti mengalami peningkatan dalam hal pengumpulan dan pengelolaan dana Zakat, Infak, dan Sedekah (ZIS). Hal ini dibuktikan dengan semakin bertambahnya perolehan dan meningkatnya pula dana yang disalurkan melalui program-program yang telah dibentuk (Dokumentasi BAZNAS Kabupaten Kepulauan Meranti).

\section{Pengelolaan Dana Zakat Untuk Pembiayaan Pendidikan Anak Dhuafa}

Dalam wawancara dengan penulis, Muslim (3 Desember 2020) mengatakan bahwa pada dasarnya dana zakat yang telah dikumpulkan oleh BAZNAS Kabupaten Kepulauan Meranti akan didistribusikan ke berbagai bidang utama yakni bidang dakwah, pendidikan, sosial dan ekonomi, serta kesehatan yang sudah dikategorikan dalam beberapa program yakni program Meranti Agamis, Meranti Cerdas, Meranti Produktif, Meranti Sehat, Meranti Peduli dan Meranti Konsumtif. Namun agar penelitian ini tidak melebar dan mampu memberikan hasil yang informatif, maka penelitian ini difokuskan pada bidang pendidikan atau pada program Meranti Cerdas, yakni bagaimana pengelolaan dana zakat untuk pembiayaan pendidikan anak dhuafa.
Adapun kebijakan dan estimasi yang dilakukan yaitu dengan membentuk UPZ (Unit Pengumpul Zakat) diseluruh SKPD, Instansi dengan tujuan memaksimalkan penghimpunan dan pendistribusian zakat dengan menerapkan sistem bagi hasil $30 \%$.

Pengelolaan dana zakat untuk pembiayaan pendidikan dalam hal ini pada program Meranti Cerdas, BAZNAS Kabupaten Kepulauan Meranti mengadakan beasiswa bagi kaum dhuafa disetiap sekolah dengan mengfungsikan dana bagi hasil $30 \%$ disekolah yang sudah membentuk UPZ dan menghimpun dana zakat, dengan jumlah persentase $15 \%$ dari zakat yang terhimpun. Adapun pengelolaan dana zakat untuk pembiayaan pendidikan anak dhuafa oleh BAZNAS Kabupaten Kepulauan Meranti pada program Meranti Cerdas yakni :

1. Melakukan program pembiayaan pendidikan dengan menyalurkan bantuan perangkat komputer ke salah satu sekolah yakni ke Madrasah Aliyah (MA) Hidayatul Mubtadiin, yang mana sekolah ini berada pada daerah yang tertinggal, terpencil, dan termiskin yang terletak jauh dari keramaian masyarakat. Sekolah ini berada di Desa Semukut, Kecamatan Pulau Merbau, Kabupaten Kepulauan Meranti, Provinsi Riau. Kegiatan pengadaan perangkat komputer ini bertujuan untuk mengenalkan teknologi kepada siswa khususnya dibidang komputer karena daerah ini belum menikmati perkembangan teknologi yang terjadi. Banyaknya komputer yang disalurkan yakni sebanyak 6 unit dan dapat dirasakan manfaatnya oleh 122 siswa yang telah didampingi oleh 6 orang guru dalam proses belajar mengajar. Selain itu juga, BAZNAS Kabupaten Kepulauan Meranti juga menyalurkan 1 unit mesin diesel $5 \mathrm{~kg}$ sebagai penunjang proses pembelajaran siswa dalam 
menggunakan komputer tersebut (Eli Sumarni, wawancara, 4 Desember 2020).

2. Melakukan program pembiayaan pendidikan dengan menyalurkan bantuan 20 paket Al-Qur'an ke salah satu TPA yakni TPA Darul Ilmi, penyaluran bantuan paket Al-Qur'an ini bertujuan untuk melengkapi sarana belajar dan meningkatkan kualitas para santri dalam belajar ilmu AlQur'an. TPA Darul Ilmi ini terletak di Desa Tanjung Sari, Kecamatan Tebing Tinggi, Kabupaten Kepulauan Meranti, Provinsi Riau.

3. Memberikan bantuan pada Taman Pendidikan Al-Qur'an (TPA) Darul Ilmi dengan cara membantu perluasan gedung dan memenuhi fasilitas TPA. BAZNAS Kabupaten Kepulauan Meranti menyalurkan dana zakat untuk kepentingan TPA Darul Ilmi diantaranya untuk merenovasi gedung yang meliputi penambahan luas gedung $(5 \times 2,5$ meter dari luas awal 5 x 5 meter), penambahan kawat ventilasi, pengecatan ulang gedung dan pembuatan plang TPA. Dalam rangka memenuhi fasilitas, BAZNAS Kabupaten Kepulauan Meranti mensupport sarana belajar seperti satu unit lemari, karpet alas lantai, papan tulis dan perlengkapan lainnya yang dibutuhkan.

4. Selain memberikan pembiayaan untuk pendidikan, BAZNAS Kabupaten Kepulauan Meranti juga mendampingi kegiatan pendidikan TPA Darul Ilmi seperti rutinitas belajar Al-Qur'an, praktek ibadah dan muhadarah, mendampingi kerajinan tangan santri, serta kegiatan pengajian yang diadakan setiap akhir bulan.

5. Memberikan beasiswa kepada enam calon mahasiswa asal Kabupaten Kepulauan Meranti yang akan menempuh pendidikan tinggi di
Sekolah Tinggi Agama Islam AnNawawi (STAIAN) Berjan Kabupaten Purworejo yang berbasis pondok pesantren. Sehingga para mahasiswa ini tidak hanya menjalani pendidikan formal yakni perkuliahan tetapi akan mendapat kesempatan mendalami ilmu agama di pesantren. Calon mahasiswa ini ditanggung biayanya secara keseluruhan oleh BAZNAS Kabupaten Kepulauan Meranti, mulai dari biaya pendidikan, kebutuhan pangan, dan lain sebagainya. Dengan harapan setelah selesai menempuh pendidikan, mereka akan dibutuhkan untuk membantu memperkuat kelembagaan Baznas di Kabupaten Kepulauan Meranti, karena STAIAN dipercaya sebagai kampus untuk mendidik calon mahasiswa yang memiliki jurusan yang linier dengan manajemen pengelolaan zakat.

6. Melakukan peningkatan kualitas pendidikan dengan memberikan beasiswa kepada masing-masing siswa yang tergolong kurang mampu dibeberapa sekolah yang ada di Kabupaten Kepulauan Meranti. Nominal beasiswa yang diberikan kepada masing-masing siswa Rp. 300.000 - Rp. 500.000 sesuai dengan kebutuhan para peserta didik. Dengan harapan dapat sedikit membantu kebutuhan akan perlengkapan serta alat tulis siswa dalam proses belajar di sekolah.

7. Memberikan beasiswa kepada mahasiswa yang kurang mampu perekonomiannya tetapi tergolong pintar, yakni dengan memberikan bantuan pembayaran uang semester pada mahasiswa yang bersangkutan. Dalam hal ini mahasiswa yang dibantu oleh BAZNAS Kabupaten Kepulauan Meranti adalah mahasiswa Universitas Riau sekitar 7 orang. 
8. Memberikan bantuan dana atau gaji kepada tenaga pengajar, dalam hal ini guru ngaji di Kabupaten Kepulauan Meranti yang namanya sudah terdaftar di BAZNAS Kabupaten Kepulauan Meranti sebagai penerima bantuan karena tergolong kurang mampu. Hal ini bertujuan agar guru ngaji tersebut lebih semangat dalam memberikan ilmu dan membimbing anak-anak dipelosok desa tentang ilmu agama, dengan demikian anak-anak juga mendapat perhatian penuh dalam belajar mengaji (Khozin, wawancara, 31 November 2020).

\section{Kriteria Penerima Pembiayaan Pendidikan}

Pada pelaksanaannya ada penyeleksian anak-anak yang masuk kedalam penerima pembiayaan pendidikan oleh BAZNAS Kabupaten Kepulauan Meranti, kriteria anak-anak yang diutamakan sebagai penerima beasiswa tergolong sebagai berikut: (1) fakir miskin, yatim/piatu (2) beragama Islam (3) masih sekolah (4) adanya surat keterangan tidak mampu dari RT setempat (5) serta anak-anak yang tergolong pintar dengan bukti nilai raport yang sudah diserahkan ke tim BAZNAS (6) berdomisili di Kabupaten Kepulauan Meranti. Setelah itu akan ditindaklanjuti oleh tim BAZNAS Kabupaten Kepulauan Meranti dengan mensurvei langsung kelapangan setelah data penerima bantuan pendidikan diterima (Dokumentasi BAZNAS Kabupaten Kepulauan Meranti).

\section{KESIMPULAN}

BAZNAS Kabupaten Kepulauan Meranti sebagai lembaga yang bertujuan untuk mewujudkan infrastruktur ekonomi masyarakat yang lebih kuat melalui pembiayaan dana zakat. Salah satu langkah dalam mewujudkan tujuan tersebut adalah dengan membuat program pembiayaan untuk pendidikan. Dari pemaparan hasil dan pembahasan penelitian di atas, maka pengelolaan dana zakat yang telah diterapkan untuk meningkatkan kualitas pendidikan anakanak dhuafa disalurkan dalam program Meranti Cerdas. Adapun pengelolaan dana zakat tersebut yakni menyalurkan bantuan perangkat komputer, bantuan 20 paket AlQur'an, membantu perluasan gedung dan memenuhi fasilitas TPA, mendampingi kegiatan pendidikan TPA, memberikan beasiswa kepada enam calon mahasiswa An-Nawawi (STAIAN) yang berbasis pondok pesantren, memberikan beasiswa kepada masing-masing siswa yang tergolong kurang mampu, memberikan beasiswa kepada mahasiswa yang kurang mampu perekonomiannya tetapi tergolong pintar, serta memberikan bantuan dana atau gaji kepada tenaga pengajar. Selain itu, kriteria siswa penerima pembiayaan pendidikan yakni fakir miskin atau yatim piatu, beragama Islam, masih sekolah, adanya surat keterangan tidak mampu, anak-anak yang tergolong pintar, dan berdomisili di Kabupaten Kepulauan Meranti.

\section{DAFTAR PUSTAKA}

Ahmad, Atabik. 2015. Manajemen pengelolaan zakat yang efektif di era kontemporer. Zakat dan Wakaf, 2(1), 23.

Anis, Fahami M. 2016. Effectiveness of zakat-based programs on poverty alleviation and economic empowerment of poor women: a case study of bangladesh. Journal of Islamic Monetary Economics and Finance, 1(2), 29.

Azwar, Syaifuddin. 2004. Metode Penelitian. Pustaka Pelajar. Yogyakarta.

Basri, Helmi. 2010. Fiqih Ibadah (Panduan Ibadah Seorang Muslim). Suska Press. Pekanbaru. Depdikbud, 2002. Kamus Besar Bahasa Indonesia. Balai Pustaka. Jakarta. 
Dedi, Supriyadi. 2003. Satuan Biaya Pendidikan Dasar dan Menengah. Remaja Rosda Karya. Bandung.

Hafidhudin, Didin. 2002. Zakat Dalam Perekonomian Modern. Gema Insani Press. Jakarta.

Hasan, Ali. 2000. Zakat Pajak Asuransi dan Lembaga Keuangan. PT Raja Grafindo Persada. Jakarta.

Huda, Nurul. 2010. Lembaga Keuangan Islam. Prenadamedia Group. Jakarta.

Hadari. Nawawi. 1997. Administrasi Pendidikan. PT. Toko Gunung Agung. Jakarta.

H.B. Sutopo. 2002. Pengantar Penelitian Kualitatif. Universitas Sebelas Maret Press. Surakarta.

Lexy J, Moleong. 2002. Metode Penelitian Kualitatif. PT. Remaja Rosdakarya. Bandung.

Munadi, Muhammad. 2004. Instrumen religius philantropy sebagai alternatif pembiayaan pendidikan Islam. Jurnal at Tarbawi, 2(1), 6778.

Mhd Ali, Nuruddin. 2006. Zakat Sebagai Instrumen Dalam Kebijakan Fiskal. PT RajaGrafindo Persada. Jakarta.

Nanang, Fatah. 2002. Ekonomi dan Pembiayaan. PT. Remaja Rosdakarya. Bandung.

Nanang, F. 2007. Indikator kemandirian pembiayaan madrasah. Jurnal Edukasi, 5(1), 35.

Nurhayati, Sri. 2011. Akuntansi Syariah di Indonesia. Salemba Empat. Jakarta.

Zulkifli. 2014. Panduan Praktis Pintar Memahami Zakat. Suska Press. Pekanbaru. 